
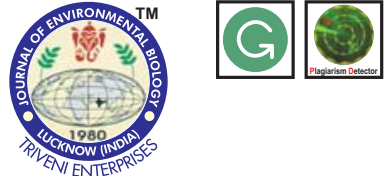

\title{
Characterisation of cholinesterase from kidney tissue of Asian seabass (Lates calcarifer) and its inhibition in presence of metal ions
}

Authors Info

N. M. Hayat', S. A. Ahmad" N. A. Shamaan', M. K. Sabullah", M. Y. A. Shukor', M. A. Syed', A. Khalid ${ }^{4}$ K. A. Khalil' and

F. A. Dahalan ${ }^{6}$

'Department of Biochemistry, Faculty of Biotechnology and Biomolecular Sciences, Universiti Putra Malaysia 43400, UPM Serdang, Selangor, Malaysia ${ }^{2}$ Faculty of Medicine and Health Sciences, Universiti Sains Islam Malaysia, 55100, Kuala Lumpur, Malaysia

${ }^{3}$ Faculty of Science and Natural Resource, Universiti Malaysia Sabah, 88400, Kota Kinabalu, Sabah, Malaysia

${ }^{4}$ Faculty of Health Sciences, Universiti Kebangsaan Malaysia, 50300, Kuala Lumpur, Malaysia

${ }^{5}$ Department of Biomolecular Sciences, Faculty of Applied Sciences, Universit Selangor, Malaysia

${ }^{6}$ The School of Environmental Engineering, Universiti Malaysia Perlis, 02600 , Arau, Perlis, Malaysia

${ }^{*}$ Corresponding Author Email : aqlima@upm.edu.my

Key words

Biomarker,

Cholinesterase,

Metal ions,

Lates calcarifer

Publication Info

Paper received :21.03.2015

Revised received : 30.07 .2016

Accepted : 13.09.2016

\section{Abstract}

Aim : The cholinesterase (ChE) based inhibition studies from fish were investigated and presented here emerged to be one of the great potential biomarkers for heavy metals monitoring.

Methodology : In this study, the capability of ChE extracted from the kidney of Lates calcarifer was assessed for of metal. ChE was purified through ammonium sulphate precipitation and ion exchange chromatography.

Results : The purified enzyme gave 12 fold purification with the recovery of $12.17 \%$ with specific activity of $2.889 \mathrm{U} \mathrm{mg}^{-1}$. The Michaelis-Menten constant $\left(\mathrm{K}_{\mathrm{m}}\right)$ and $\mathrm{V}_{\text {max }}$ value obtained was $0.1426 \mathrm{mM}$ and $0.0217 \mu \mathrm{mol}$ $\mathrm{min}^{-1} \mathrm{mg}^{-1}$, respectively. The enzyme has the ability to hydrolyse acetylthiocholine iodide (ATC) at a faster rate compared to other two synthetic substrates, propionylthiocholine iodide (PTC) and butyrylthiocholine iodide (BTC). ChE gave highest activity at 20$30^{\circ} \mathrm{C}$ in Tris-HCl buffer $\mathrm{pH}$ 8.0. The results showed that cholinesterase from $L$. calcarifer kidney was very sensitive to sensitive to copper and lead after being tested argentum, arsenic, cadmium, chromium, copper, cobalt, mercury, nickel, lead and zinc.

Interpretation : The effect of heavy metals studied on the activity of $\mathrm{ChE}$ differed from each other. The result of the study can be used as a tool for further developing a biomarker for the detection of heavy metals in aquatic ecosystems. In addition, the information can also be used for designing a kit, that would give a rapid and accurate result.

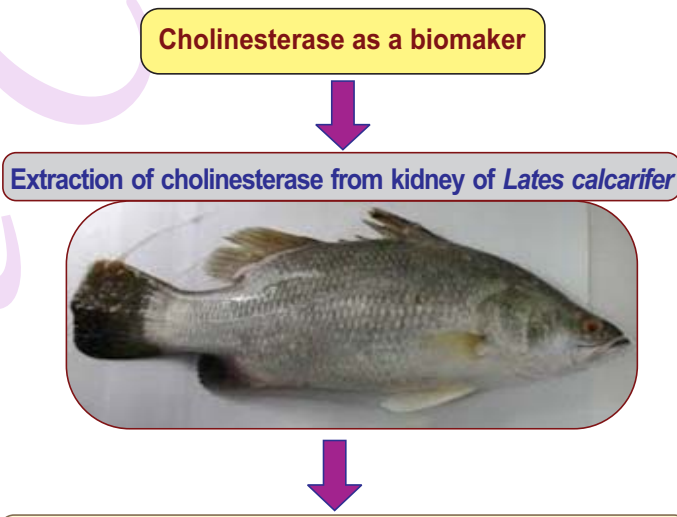

Purification of cholinesterase from kidney of Lates calcarifer - ammonium sulphate precipitation • ion exchange chromatography

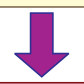

Optimization of cholinesterase - Substrates - pH • Temperature

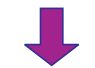

Effect of 10 metal ions

- silver (II) • arsenic (V) • cadmium (II) • chromium (VI) • cobalt (II) • copper (II) - mercury (II) $\cdot$ nickel (II) - lead (II) - zinc (II) - Half maximal inhibitory concentration $\left(\mathrm{IC}_{50}\right)$

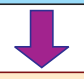

Development of biomarker for the detection of heavy metals in aquatic ecosystems 


\section{Introduction}

Cholinesterases ( $\mathrm{ChE}$ ) are serine hydrolases, which can be divided into two molecular types, namely acetylcholinesterase (AChE) and pseudocholinesterase (PChE) based on their response towards selective inhibitor and substrate preferences (Villatte and Bachmann, 2002). In biological systems, some heavy metals are present in the form of metal ions and are required only in trace amount for biochemical reactions (Cohen et al., 2000; Ma et al., 2009). Bioaccumulation that occurs mainly in vital organs due to high concentration of heavy metals will give an adverse effect to the physiological functions (Singh et al., 2011).

Formation of enzyme-substrate complex is facilitated by metal ions. However, they have a tendency to react with terminal $-\mathrm{OH}$ and $-\mathrm{SH}$ functional groups as they bind with the allosteric sites that caused the conformational changes making the substrate failed to bind at specific site of the enzyme (Glusker et al., 1999). Metal ions have the capability to inhibit ChE activity as they are considered as neurotoxic compounds (Elumalai et al., 2002). Metal ions such as copper, cadmium, mercury and chromium are strong inhibitors of ChE (Tilton et al., 2011; Hayat et al., 2015).

Fish are sensitive to toxicants as they are exposed directly to these pollutants through skin by absorption, breathing and oral intake (Mathur and Singh, 2006). The most studied biomarkers are ChE based, which use two types of $\mathrm{ChE}$, acetylcholinesterase (AChE) and butyrylcholinesterase (BChE) (Ahmad et al., 2016a; Hayat et al., 2016). Further more, aquatic organisms exhibit heavy metals intoxication prior to their death and hence, are used as model organisms (Cokugras, 2003; Adedeji, 2011).

BChE are crucial for different parts of immune system and considered as one of the core detoxifying enzymes (Archana et al., 2011). BChE protects AChE from being inhibited by nerve agent such as pesticides (Soreq and Zakut, 1993). Biomarkers are the best tools in determining the effect of pesticides and heavy metals. However, they show irreversible effects on ChE (Sabullah et al., 2015a; Ahmad et al., 2016b).

Cholinesterase activity in the kidney of aquatic organisms is currently not well characterised and documented. Hence, in the present study importance of ChE activity in the Asian seabass kidney and its effect when exposed to metal ions.

\section{Materials and Methods}

Extraction, purification and enzyme activity of cholinesterase: $L$. calcarifer measuring $25 \mathrm{~cm}$ in length and weighing approximately $1.0 \mathrm{~kg}$ were procured from Pusat Sains Marin UPM in Telok Kemang, Port Dickson. The kidney of $L$. calcarifer was dissected, weighed and homogenised. The supernatant of the sample was collected after centrifugation at
$10,000 \mathrm{xg}$ for $30 \mathrm{~min}$ at $4{ }^{\circ} \mathrm{C}$ and stored at $-20^{\circ} \mathrm{C}$ for purification. The crude extract derived from above was gradually added with ammonium sulfate powder to obtain 0-30, 30-40, 40-50, 50-60, $60-70$ and $70-80 \%$ saturation levels. A $15 \mathrm{ml}$ of supernatant was loaded into the ion exchange column containing DEAE-Cellulose for purification process. ChE of $L$. calcarifer which was bounded to the matrix was eluted by loading $25 \mathrm{mM}$ sodium phosphate buffer ( $\mathrm{pH} 7.0)$ containing $1 \mathrm{M} \mathrm{NaCl}$ into the column.

Enzyme activity and protein concentration determination was then experimented. Native polyacrylamide gel electrophoresis (Native-PAGE) was carried out following the method of Laemmli (1970). The separated protein was visualised using Coomasie Brilliant Blue G-250 (silver blue). Protein marker with a broad range of molecular weight (MW) was used that contained myosin, beta-galactosidase, BSA, ovalbumin, carbonic anhydrase, soybean trypsin inhibitor, lysozyme and aprotinin with molecular weight of 198, 103, 58, 41,27, 20, 15 and $6 \mathrm{kDa}$, respectively (Bio-Rad, UK). The stained gel was then visualised using calibrated G-800 densitometer (Bio-Rad, UK). Retention factor was calculated by dividing migration of protein marker with migration of silver blue.

A slight modification of Ellman et al. (1961) method using 96-well microplate was chosen to examine the enzyme activity of L. calcarifer, at wavelength of $405 \mathrm{~nm}$. Protein content was determined using the method developed by Bradford (1976). Bovine serum albumin was used as standard for quantitative determination of protein. All the tests were carried out in triplicates and the assays were run in dark.

Optimal assay determination : Three different synthetic substrates, namely ATC, BTC and PTC at 0.1, 0.5, 1.0, 2.0, 5.0 and $10.0 \mathrm{mM}$ were concentrations used for determining the substrate specificity for $\mathrm{ChE}$ extracted from the kidney of $L$. calcarifer in sodium phosphate buffer (0.1 M, pH 7.0).

Determination of optimum $\mathrm{pH}$ for enzyme was done by incubating $L$. calcarifer $C h E$ with an overlapping buffer system of $0.1 \mathrm{M}$ acetate buffer ( $\mathrm{pH} 3$ to 5), $0.1 \mathrm{M}$ sodium phosphate buffer (pH 6 to 8 ) and $0.1 \mathrm{M}$ tris-HCl buffer ( $\mathrm{pH} 7$ to 10). The optimal temperature of the enzyme was determined after incubating $\mathrm{ChE}$ sample at different temperatures ranging from 15 to $50^{\circ} \mathrm{C}$. Beyond this temperature range, $\mathrm{ChE}$ was observed to be denatured.

Effect of metal ion : The enzyme activity was experimented by incubating ten types of metal ions viz., silver (II), arsenic (V), cadmium (II), chromium (VI), cobalt (II), copper (II), mercury (II), nickel (II), lead (II) and zinc (II) with L. calcarifer ChE. Half maximal inhibitory concentration $\left(\mathrm{IC}_{50}\right)$ was determined by incubating the ChE sample with inhibitors of different concentrations for $30 \mathrm{~min}$. 


\section{Results and Discussion}

ChE extracted from the kidney of $L$. calcarifer was purified by using three-step procedures such as sample extraction, ammonium sulfate precipitation and ion exchange chromatography by using DEAE-Cellulose column. At the end of the study, nearly $12.17 \%$ enzyme recovery was achieved. The purified ChE showed the specific activity of $2.889 \mathrm{U} \mathrm{mg}^{-1}$ of protein (Table 1). The presence of ChE in fish kidney has already been reported by Sol'e et al. (2012). The presence of ChE in other organs of fish such as liver (Sabullah et al., 2014), muscle (Rodr'Iguez-Fuentes et al., 2008), plasma and brain tissues (Tham et al., 2009; Sabullah et al., 2015b) have been well documented. The crude extract was eliminated by a large portion of proteins of low molecular mass ammonium sulfate precipitation with $50-60 \%$ saturation (Fig. 1). A single protein band for ChE from DEAE-Cellulose ion exchange chromatography at lane 2 as indicated, the purified ChE was determined to have a molecular weight of $124 \mathrm{kDa}$ after molecular weight of standard proteins was interpolated as shown in Fig. 2.

An obeyed Michaelis-Menten kinetics was observed in hydrolysation of three different substrates, namely acetylthiocholine iodide (ATC), butyrylthiocholine iodide (BTC) and propionylthiocholine iodide (PTC) at varying concentrations by ChE (Fig. 3). Increasing substrate concentration influenced the increase in hydrolytic activity as shown in all the three reactions. Conversely, the enzyme exhibited a plateau state at above $1 \mathrm{mM}$ substrate concentration. ATC recorded the lowest $\mathrm{K}_{\mathrm{m}}$ values compared to PTC and BTC (Table 2). This result shows that the affinity of the enzyme towards ATC substrate was greater when BTC and PTC was used as substrate. In the study also, ATC displayed highest ratio of catalytic efficiency $\left(\mathrm{V}_{\text {max }} / \mathrm{K}_{\mathrm{m}}\right)$, thus was selected as an ideal substrate for this assay. An increase in $V_{m a x} / K_{m}$ value indicates the intensity of enzyme affinity. The results of the substrates study show that the value of $V_{\max } / K_{m}$, when tested with ATC, was maximum as compared to PTC and BTC (Fig. 3). Thus, it can be concluded that $\mathrm{ChE}$ from $L$. calcarifer kidney had a

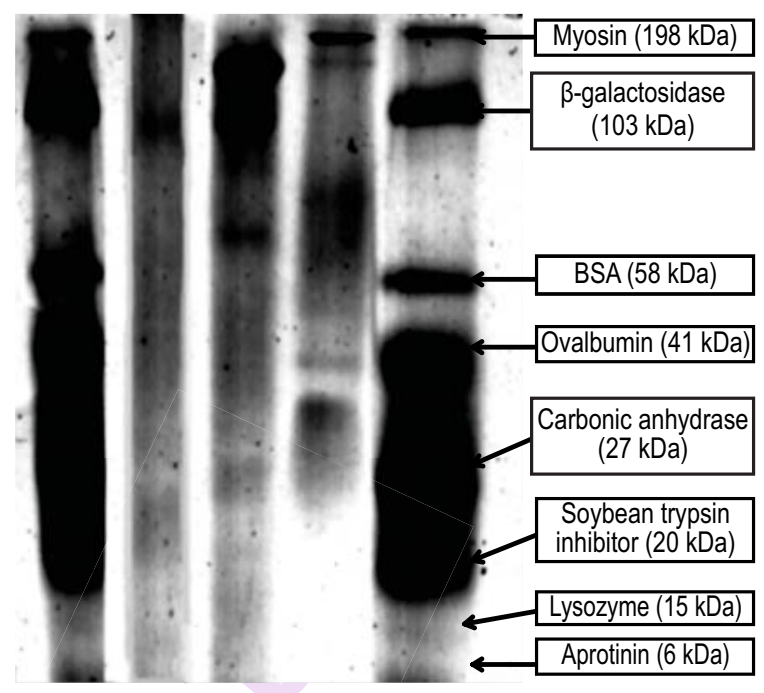

Fig. 1 : Diagram of Native-PAGE for ChE extracted from L. calcarifer kidney. Lane 1 and 5 is broad range protein marker. Lane 2 is sample fraction from DEAE-Cellulose ion exchange chromatography. Lane 3 show the pellet precipitated by ammonium sulphate of $50-60 \%$ saturation and Lane 4 is crude extract of $L$. calcariferkidney

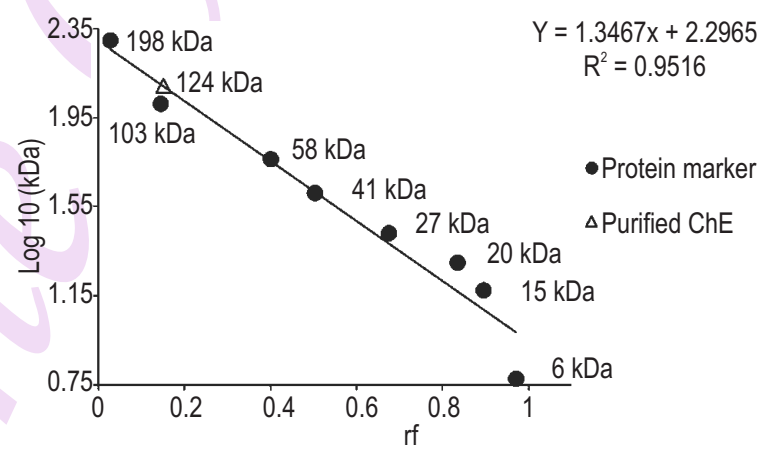

Fig. 2 : Retention factor ( $r f)$ of intrapolation of protein markers to determine the molecular weight of purified ChE from $L$. calcarifer kidney. The triangles indicated overlapping of purified $\mathrm{ChE}$ with other protein

Table 1 : Total and specific activity of ChE extracted from the kidney of $L$. calcarifer

\begin{tabular}{llllll}
\hline Procedure & $\begin{array}{l}\text { Total protein } \\
(\mathbf{m g})\end{array}$ & $\begin{array}{l}\text { Total ChE activity } \\
(\mathbf{U})\end{array}$ & $\begin{array}{l}\text { Specific activity } \\
\left(\mathbf{U ~ m g} \mathbf{~ g}^{-1}\right.\end{array}$ & Purification fold & $\begin{array}{l}\text { Yield } \\
(\%)\end{array}$ \\
\hline Crude & 39.555 & 9.615 & 0.243 & 1 & 100 \\
Ammonium sulphate precipitation & 0.725 & 1.633 & 2.254 & 9 & 16.98 \\
DEAE-Cellulose & 0.405 & 1.17 & 2.889 & 12 & 12.17 \\
\hline
\end{tabular}

Table 2: Comparison of the maximum velocity $\left(\mathrm{V}_{\max }\right)$ and biomolecular constant $\left(\mathrm{K}_{\mathrm{m}}\right)$ for ATC, BTC and PTC of L. calcarifer kidney ChE

\begin{tabular}{llll}
\hline & ATC & BTC & PTC \\
\hline $\mathrm{V}_{\text {max }}\left(\mu \mathrm{mol} \mathrm{min}{ }^{-1} \mathrm{mg}^{-1}\right)$ & 0.0217 & 0.0178 & 0.0178 \\
$\mathrm{~K}_{\mathrm{m}}(\mathrm{mM})$ & 0.1426 & 0.3853 & 0.1214 \\
$\mathrm{~V}_{\text {max }} / \mathrm{K}_{\mathrm{m}}$ & 0.1525 & 0.0461 & 0.1469 \\
\hline
\end{tabular}


higher affinity towards ATC. Nevertheless, the enzyme inhibition was noticed in the presence of excess substrates. Based on these results, implication can be made that the purified $\mathrm{ChE}$ was a type of acetyl cholinesterase (AChE).

The optimum $\mathrm{pH}$ for $\mathrm{ChE}$ activity was determined after its purification. The effects of different range of $\mathrm{pH}$ towards $\mathrm{ChE}$ activity have been also investigated. The optimum $\mathrm{pH}$ for $\mathrm{ChE}$ from $L$. calcarifer kidney fell between pH 7.0 and 8.0 (Fig. 4) of potassium phosphate and Tris- $\mathrm{HCl}$ buffer $(\mathrm{p}>0.05)$. 0.1 M Tris$\mathrm{HCl}$ buffer, $\mathrm{pH} 8.0$ was selected as an optimum assay condition because it showed highest mean point of data when these two types of buffer were compared. Interaction of substrate with ChE at low $\mathrm{pH}$ was disrupted by high concentration of protons due to existence of protonated imidazole group of histidine at catalytic triad of the enzyme (Masson et al., 2002). The mechanism of ChE may be affected due to alteration in histidine conformation (Masson, 2012). Whereas at high pH, binding of enzyme and substrate was also affected due to change of substrate charge.

The effects of different temperatures on ChE activity is depicted in Fig. 5. The optimum ChE activity was observed between 20 and $30^{\circ} \mathrm{C}(p>0.05)$. At lower temperature, the activity of ChE was minimum, but as the temperature increased the activity reached maximum until reaching the given velocity thus, exhibiting a bell shaped curve. After that, the ChE activity decreased abruptly at higher temperatures. The optimum temperature for $L$. calcarifer ChE matches with the ambient temperature. Although, kinetic energy was limited at low temperature, ChE activity was retarded but not denatured thus, PTC could not be hydrolysed completely. However, the activity significantly increased as temperature reached maximum point. In the present study, maximum activity of $L$. calcarifer $\mathrm{ChE}$ was achieved at $20-30^{\circ} \mathrm{C}$, but the activity briskly decreased beyond this temperature. This is inagreement with the theory; protein will undergo denaturation because they loose their stability at high temperature (Gaudy et al., 2000).

Ten selected metal ions with the concentration of $10 \mathrm{mgl}^{-1}$ were incubated with $L$. calcarifer kidney sample under combined optimal assay parameters. The in vitro studies showed that $\mathrm{ChE}$ was inhibited by silver, chromium, copper, cobalt, nickel and zinc by lowering the activity to $36.55,48.10,9.10,40.18,35.01$ and $31.95 \%$, respectively when incubated with PTC (Fig. 6). Meanwhile, all these metals showed more than $50 \%$ of inhibition when incubated with BTC. $\mathrm{Cu}$ and $\mathrm{Pb}$ displayed inhibition when incubated with ATC where the activities decreased by 60 and $40.4 \%$. Frasco et al. (2007) and Wang et al. (2004) reported that copper is a strong $\mathrm{ChE}$ inhibitor. Based on the results, it can be concluded that the toxicity of tested metals at $10 \mathrm{ppm}$ varied according to the types of substrate used. All these metal ions showed significant inhibition towards ChE activity, but differed in inhibition percentage $(p<0.005)$. Earlier studies have reported that carbamate and organophosphate which also known as nerve

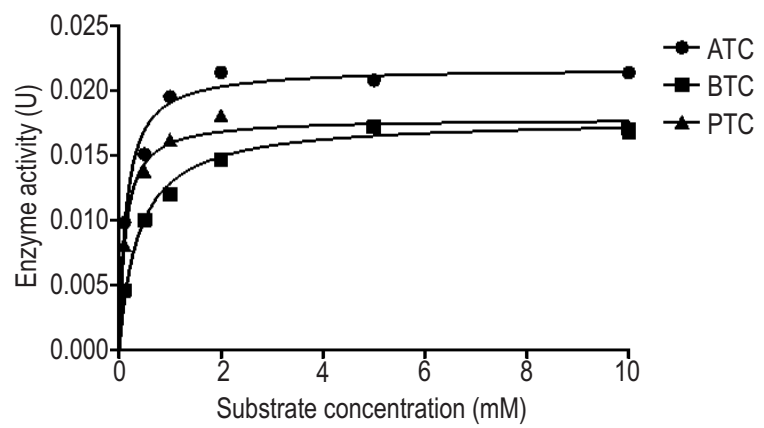

Fig. 3 : Purified ChE incubated in three synthetic substrates with different concentrations

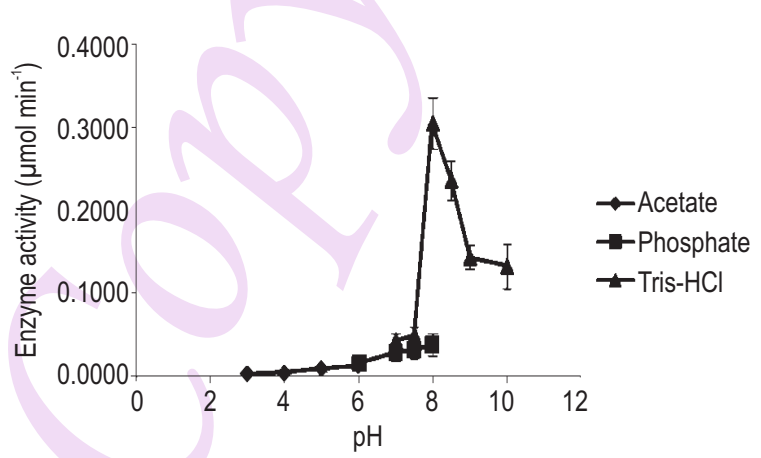

Fig. 4 : $\mathrm{pH}$ profile of $L$. calcarifer kidney on the activity of purified $\mathrm{ChE}$

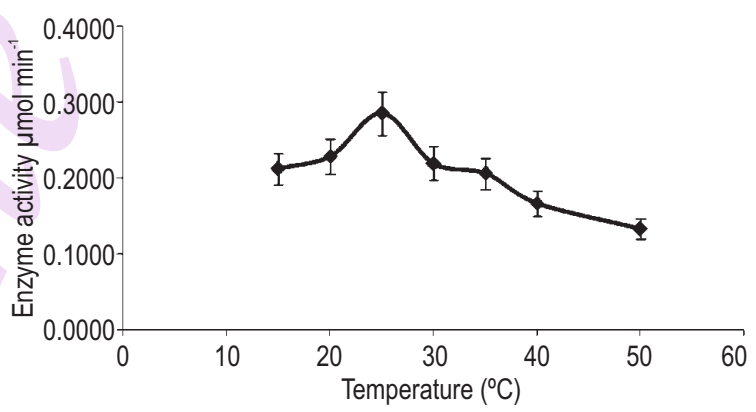

Fig. 5 : Temperature profile of $L$. calcarifer kidney on the activity of purified ChE

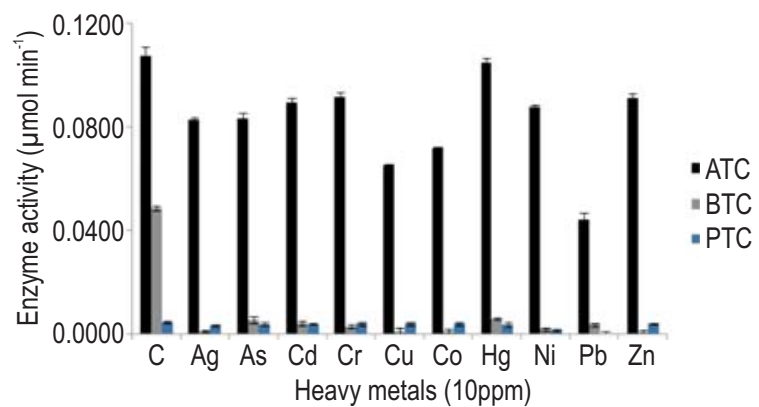

Fig. 6 : Effect of various heavy metals on the enzymatic activity of purified $\mathrm{ChE}$ from $L$. calcarifer kidney tested with three different synthetic substrates (ATC, BTC, PTC) 


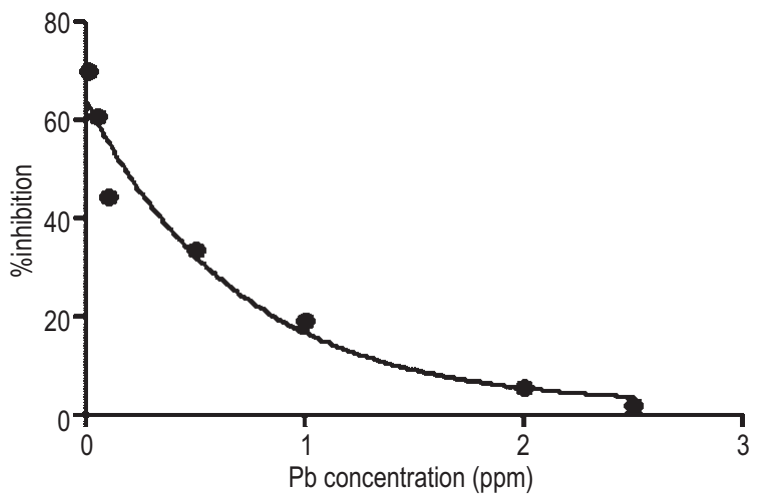

Fig. 7 : Effect of Pb concentrations on kidney ChE activity

agents can inhibit ChE activity through the process of carbamylation and phosphorylation at the active site and by blocking the binding of substrate (Kwong, 2002; Weinbroum, 2004; Rosenberry et al., 2005). Unlike pesticides, metal ions inhibition is caused by the affinity binding towards the amino acid side chain. Proteins that have histidine residues are most susceptible to metal binding such as copper and zinc (Abdelhamid et al., 2007; Rajesh et al., 2009). In the present study capability of metal ion to inhibit ChE activity extracted from the kidney of $L$. calcarifer has been verified. The intensive study has been done to know the mechanism of heavy metals inactivation of ChE by mercury (Frasco et al., 2007). They mentioned that inactivation of mercury is due to action of sulfhydryl reacting agent. The other heavy metals mechanism of inhibition still remains unknown, but in some studies it can be ventured to be caused by conservation of catalytic triad Ser-HisGlu in both AChE and BChE (Podoly et al., 2009).

Screening of heavy metals showed that kidney $\mathrm{ChE}$ of $L$. calcarifer was sensitive towards $\mathrm{Pb}$ as it inhibited the activity by more than $50 \%$. The purified kidney $\mathrm{ChE}$ was very sensitive to $\mathrm{Pb}$, which acted as an inhibitor for the enzyme. $\mathrm{IC}_{50}$ study for $\mathrm{Pb}$ was obtained for further studies is shown in Fig. 7. Enzyme activity of kidney ChE was inhibited $>50 \%$ at $0.1 \mathrm{ppm}$ concentration. Heavy metals pollution is a great health threat and the emerging development of an assay for heavy metals is anticipated to increase the efficiency of toxic xenobiotics biomonitoring (Sani et al., 2010; Kavita et al., 2011). Agrahari et al. (2006) in his study used fish, Clarias punctatus as a biomarker for monitoring the presence of insecticide. Thus, there is a possibility that $\mathrm{ChE}$ from L. calcarifer kidney can be used as an alternative method for detection of not only heavy metals, but other contaminants such detergents, dyes and pesticides.

\section{Acknowledgments}

This project was supported by the fund received from The Ministry of Science, Technology and Innovation (MOSTI),
Malaysia, under FRGS Grant no. 02-02-13-1256FR (FRGS/2/2013/SG05/UPM/ 02/16), Science fund (02-01-04sf1473) and Pusat Sains Marin, UPM, Telok Kemang, Port Dickson, Malaysia.

\section{References}

Abdelhamid, R.F., Y. Obara and Y. Uchida: $\pi-\pi$ interaction between aromatic ring and copper coordinated His81 imidazole regulates the blue copper active site structure. J. Biol. Inorg. Chem., 12, 165-173 (2007).

Adedeji, O.B.: Response of acetylcholinesterase activity in the brain of Clarias gariepinus to sublethal concentration of diazinon. J. Appl. Sci. Environ. Sanit., 6, 137-141 (2011).

Agrahari, S., K. Gopal and K.C. Pandey: Biomarkers of monocrotophos in a freshwater fish Channa punctatus (Bloch). J. Environ. Biol., 27, 453-457 (2006).

Ahmad, S.A., M.K. Sabullah, N.A. Shamaan, M.Y.A. Shukor, H. Jirangon, A. Khalid and M.A. Syed: Evaluation of acetylcholinesterase source from fish, Tor tambroides for detection of carbamate. J. Environ. Biol., 37, 479-484 (2016a)

Ahmad, S.A., Y.F. Wong, M.Y. Shukor, M.K. Sabullah, N.A. Yasid, N.M. Hayat, N.A. Shamaan, A. Khalid and M.A. Syed: An alternative bioassay using Anabas testudineus (climbing perch) cholinesterase for metal ion detection. Int. Food Res. J., 23, 1446-1452 (2016b)

Archana, A.S., V. Metkari and P. Patode: Effect of diazinon on acetylcholinesterase activity and lipid peroxidation of Poecilia reticulate. Res. J. Environ. Toxicol., 5, 152-161 (2011).

Bradford, M.M.: Rapid and sensitive method for quantitation of microgram quantities of protein utilizing principle of protein dye binding. Anal. Biochem., 72, 248-254 (1976).

Cohen, A., H. Nelson and N. Nelson: The family of SMF metal ion transporters in yeast cells, Biol. Chem., 275, 33388-33394 (2000).

Cokugras, A.N.: Butyrylcholinesterase: Structure and physiological importance. Tur. J. Biochem., 28, 54-61 (2003)

Ellman, G.L., K.D. Courtney, V. Andres and R.M. Featherstone: A new and rapid colorimetric determination of acetylcholinesterase activity. Biochem. Pharmacol.,7, 88-95 (1961).

Elumalai, M., C. Antunes and L. Guilhermino: Effects of single metals and their mixtures on selected enzymes of Carcinus maenas. WaterAir Soil Pollut., 141, 273-280 (2002).

Frasco, M.F., J. Colletier and M. Weik: Mechanisms of cholinesterase inhibition by inorganic mercury. FEBS J., 274, 1849-1861 (2007).

Gaudy, R., G. Cervetto and M. Pagano: Comparison of the metabolism of Acartia clause and $A$. tonsa: Influence of temperature and salinity. J. Exp. Mar. Biol. Ecol, 247, 51-65 (2000).

Glusker, J.P., A.K. Katz and C.W. Bock: Metal ions in biological systems. The Rigaku J., 16, 381-412 (1999).

Hayat, N.M., N.A. Shamaan, M.K. Sabullah, M.Y. Shukor, M.A. Syed, A. Khalid, F.A. Dahalan and S.A. Ahmad: The use of Lates calcarifer as a biomarker for heavy metals detection. Rendiconti Lincei, doi: 10.1007/s12210-015-0501-7 (2016)

Hayat, N.M., N.A. Shamaan, M.Y. Shukor, M.K. Sabullah, M.A. Syed, A. Khalid, F.A. Dahalan, K.A. Khalil and S.A. Ahmad: Cholinesterasebased biosensor using Lates calcarifer (Asian Seabass) brain for detection of heavy metals. J. Chem. Pharm. Sci., 8, 376-381 (2015)

Kavita, B., J. Limbachia and H. Keharia: Hexavalent chromium sorption 
by biomass of chromium tolerant Pythium sp. J. Basic Microbiol., 51, 173-182 (2011).

Kwong, T.C.: Organophosphate pesticides: biochemistry and clinical toxicology. Ther. Drug Monit., 24, 144-149 (2002).

Laemmli, U.K.: Cleavage of structural proteins during assembly of head of bacteriophage-T4. Nature, 227, 680-685 (1970).

Ma, Z., F.E. Jacobsen and D.P. Giedroc: Metal transporters and metal sensors: How coordination chemistry controls bacterial metal homeostasis. Chem. Rev., 109, 4644-4681 (2009).

Masson, P.: Time-dependent kinetic complexities in cholinesterasecatalyzed reactions, Biochem., 77, 1147-1161 (2012).

Masson, P., L.M. Schopfer and C.F. Bartelsetal: Substrate activation in acetylcholinesterase induced by low $\mathrm{pH}$ or mutation in the $\pi$ cationsubsite. Biochimicaet Biophysica Acta, 1594, 313-324 (2002).

Mathur, S.M. and J.K. Singh: Chemical spraying in agriculture and its environmental impact. In: All India seminars on environmental impact assessment. The Institution of Engineers (I), Udaipur, India, pp. 50-56(2006).

Podoly, E., D.E. Shalev and S. Shenhar-Tsarfaty: The butyrylcholinesterase $\mathrm{K}$ variant confers structurally derived risks for Alzheimer pathology. J. Biol. Chem., 284, 17170-17179 (2009).

Rajesh, R.V., A.S. Balasubramanian and R. Boopathy: Evidence for presence of $\mathrm{Zn}^{+2}$ binding site in acetylcholinesterase. Biochimie, 91, 526-532 (2009).

Rodr' Iguez-Fuentes, G., J. Armstrong and D. Schlenk: Characterization of muscle cholinesterases from two demersal flatfish collected near a municipal wastewater outfall in Southern California. Ecotoxicol. Environ. Safe.,69, 466-471 (2008).

Rosenberry, T.L., J.L. Johnson, B. Cusack, J. L. Thomas, S. Emani and K. S. Venkatasubban: Interactions between the peripheral site and the acylation site in acetylcholinesterase. Chemico-Biol. Inter., 157-158, 181-189 (2005).

Sabullah, M.K., M.R. Sulaiman, M.Y Shukor, M.A. Syed, N.A. Shamaan, A. Khalid and S.A. Ahmad: The assessment of cholinesterase from the liver of Puntius javanicus as detection of metal ions. Sci. World J., 1-9 (2014).
Sabullah, M.K., M.R. Sulaiman, M.Y. AbdShukor, N.A. Shamaan, A Khalid and S.A. Ahmad: In vitro and in vivo effects of Puntius javanicus cholinesterase by copper, Fresenius Environ. Bull., 24, 4615-4621 (2015a).

Sabullah, M.K., S.A. Ahmad, M.Y. Shukor, N.A. Shamaan, A. Khalid, A.J. Gansau, F.A Dahalan and M.R. Sulaiman: Acetylcholinesterase from Puntius javanicus for the detection of carbamates and organophosphates. J. Chem. Pharm. Sci., 8, 348-353 (2015b).

Sani, R.K., G. Rastogi, J.G. Moberly, A. Dohnalkova, T.R. Ginn, N. Spycher, R.V. Shende and B.M. Peyton: The toxicity of lead to Desulfovibrio desulfuricans $\mathrm{G} 20$ in the presence of goethite and quartz. J. Basic Microbiol., 50, 160-170 (2010).

Singh, R., N. Gautam, A. Mishra and R. Gupta: Heavy metals and living systems: an overview. Indian J. Pharmacol., 43, 246-253 (2011).

Sol'e, M., S. Vega and I. Var' o: Characterization of type "B" esterases and hepatic CYP450 isoenzymes in Senegalese sole for their further application in monitoring studies. Ecotoxicol. Environ. Safe., 78, 72-79 (2012).

Soreq, H. and H. Zakut: Human cholinesterase and anticholinesterase. Academic Press, San Diego, CA., p. 314 (1993).

Tham, L.G., N. Perumal, M.A. Syed, N.A. Shamaan and M.Y. Shukor: Assessment of Clarias batrachus as a source of acetylcholinesterase (AChE) for the detection of insecticides. J. Environ. Biol., 30, 135-138 (2009).

Tilton, F.A., T.K. Bammler and E.P. Gallagher: Swimming impairment and acetylcholinesterase inhibition in zebrafish exposed to copper or chlorpyrifos separately, or as mixtures. Comp. Biochem. Physiol. C Toxicol. Pharmacol., 153, 9-16 (2011).

Villatte, F. and T.T. Bachmann: How many genes encode cholinesterase in arthropods? Pest. Biochem. Physiol., 73, 122-129 (2002).

Wang, Y.X., A.T. Boeck, E.G. Duysen, M. Van Keuren, T.L. Saunders and O. Lockridge: Resistance to organophosphorus agent toxicity in transgenic mice expressing the $\mathrm{G} 117 \mathrm{H}$ mutant of human butyrylcholinesterase. Toxicol. App. Pharmcol., 196, 356-366 (2004).

Weinbroum, A.A.: Pathophysiological and clinical aspects of combat anticholinesterase poisoning. Br. Med. Bull., 72, 119-133 (2004). 